\title{
A conversation with $C$. Ronald Kahn
}

C. Ronald (Ron) Kahn of the Joslin Diabetes Center at Harvard Medical School is a physician-scientist who illuminated much of what we appreciate about the insulin receptor and the means by which it signals. He previously served as president of the American Society for Clinical Investigation and is the scientist with the most publications in the JCI. See the full interview on the JCI website https://www. jci.org/videos/cgms to hear more about Dr. Kahn's (Figure 1) political aspirations beyond the presidency of ASCI and to hear who told him he'd never be a big deal in endocrinology.

JCI: What you were like as a kid, and where did you grow up?

Kahn: My father was a merchant who had been born in the Ukraine. He came to the US at about 12. My mom was born in the States. They got married in Louisville, Kentucky, and my brother and I were born and raised there. I went to the public school system there; I had a couple of very cool friends actually, one who became quite a successful artist. He and I would hang around in an old Model A Ford that we had fixed up. I was always really interested in science, and my parents pushed my brother and I to be doctors. My brother became a $\mathrm{PhD}$, and I became an $\mathrm{MD}$, but we both did biomedical research, and I think my parents were very proud of us.

JCI: By my calculations, you graduated from University of Louisville with a chemistry degree by the time you were 20 .

Kahn: My brother graduated by 19, so I had a role model. I decided to do all my undergraduate studies in three years, as I knew I wanted to go to medical school. As you'll soon hear, I'm always strongly influenced by teachers or mentors who are impressive; when I was an undergraduate, probably the professor who impacted me the most was Tom Crawford, the head of the Department of Chemistry. He was doing NMR spectroscopy, which was really pretty new at the time. I worked in the summers doing research with him.

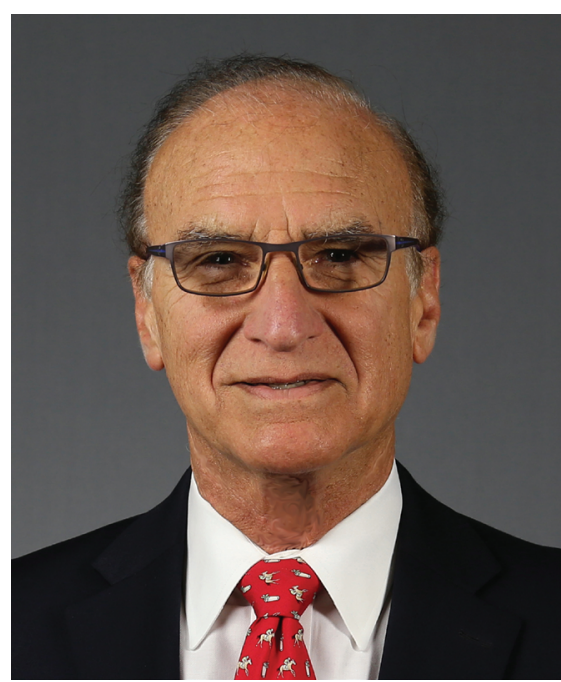

Figure 1. Ron Kahn. Image courtesy of Harvard Medical School and the Joslin Diabetes Center.

JCI: Did you have a fixation on endocrinology as you went into medical school?

Kahn: The fact that I'm an endocrinologist is almost happenstance. Almost everything I tried I liked, and because I was influenced by different people in my career, I thought about different areas of specialty. My most influential professor at medical school was a gastroenterologist, so when I first graduated from medical school and started my internship and residency, I thought I wanted to be a gastroenterologist. I went to Washington University Barnes Hospital for my internship and residency, and there were quite a number of very influential professors there. The person who impressed me most was Neal Bricker, who was head of Nephrology, and so I thought maybe I'd become a nephrologist.

So how did I wind up in endocrinology? Well, it has to do with the NIH. At that time, when you went to the NIH, you could go in an undifferentiated mode - you could interview and match based on the science and research without having to predesignate what specialty of medicine you wanted to do. I listed people in nephrology, endocrinology, gastroenterology, and even cardiology for interviews. I must say being from Louisville was not a big advantage in this matching program. It was the Vietnam War era, and many medical students wanted to go to NIH in lieu of going into the service after they graduated. I didn't have the connections that the people at a Harvard or a Yale had. I got really lucky because my mentor at NIH, the person who I eventually matched with, was Jesse Roth, one of the great endocrinologists of the 20th century. Jesse had a very interesting way of picking people to interview: his idea was to shop "undershopped markets," kind of a merchant's idea of if everybody's trying to buy at one place, maybe you'll get better merchandise if you try someplace else and not have to compete. So while many of the people in NIH were limiting their interviews to people from Ivy League-type medical schools, Jesse figured if he could get top people from Louisville or Ohio, they'd probably hold up pretty well. That got me into endocrinology, and it's been a fit ever since.

JCI: This was just at the beginning of investigations into figuring out if insulin worked through a receptor, as opposed to signaling through second messengers.

Kahn: Bob Lefkowitz had just left the lab and done groundbreaking work on the ACTH receptor, and Jesse was very excited about the potential. He put me on a project trying to follow up on Bob's work. Unfortunately, another fellow and I worked for 11 months without being able to make any progress, so I switched over to working on the insulin receptor and my labmate changed to a different area of science. I think that the moral here is that even if you go through long periods where nothing seems to work, that doesn't mean that you will never be successful. It was clear that if we could get the insulin receptor to work, this would have even greater opportunities, and it did. We also had animal models of disease, obese mice, and quickly translated those findings into humans. It was really a very exciting time and cemented my interest both in diabetes and understanding insulin action, which has been the challenge of my lifetime.

JCI: As you went to NIH as a clinical fellow, do you recall if there were patients 
that changed the course of your thinking about your research?

Kahn: At the Clinical Center of the $\mathrm{NIH}$ we were able to collect patients from around the US who had been referred for very unusual and severe forms of insulin resistance. These patients were largely women or girls, with insulin resistance at a level that's rarely seen in a clinical setting. These patients were taking thousands and sometimes tens of thousands of units of insulin a day compared to a normal replacement dose of 40 to 50 units for an adult. I even had a patient we gave up to 10,000 units of insulin intravenously an hour.

As we tried to understand these patients, we realized that there were two clinical syndromes of insulin resistance, which we called type A and type B. Type A turned out to be patients with genetic defects in the insulin receptor, while type $B$ were patients that had autoantibodies to the insulin receptor who developed autoimmune-mediated insulin resistance. The reason that this was so important was that at that time, we could only identify the receptor by radioactive insulin binding to cells - a radioreceptor assay similar to the radioimmunoassay that made Solomon Berson and Rosalyn Yalow famous.

We didn't have the pure protein, and this was before cloning, so we didn't have any of the modern tools of molecular biology. But we were able to take advantage of these patients with autoantibodies to the insulin receptor. First, we used these to probe the receptor using immunoprecipitation and Western blotting, and ultimately, even identify the receptor tyrosine kinase activity that defined the receptor as a member of the tyrosine kinase family. All of this information - the receptor structure, the fact that it had two different kinds of subunits of two sizes that formed a tetramer, that the receptor was a tyrosine kinase that underwent autophosphorylation - all of these things were learned using patient antibodies before the receptor was purified, before the receptor was cloned, before we knew its sequence. So yes, patients can provide unique insights into disease pathophysiology and, in this case, a unique tool to study some very basic biochemistry.

JCI: After the 11 years at the NIH, what prompted you to move to Harvard and the Joslin Diabetes Center?
Kahn: I think that there were a couple of things that really made me feel like I would be good to take on the challenge of the Joslin. One was, at that time, the diabetes branch had two senior leaders, Jesse Roth and Phil Gorden, both of whom, as far as I knew, might stay forever. So I didn't see an obvious opportunity for me to assume any leadership position.

Secondly, the Joslin was at a very challenging crossroads because George Cahill, who had been head of research at the Joslin through most of the $60 \mathrm{~s}$ and 70 s, had left to become an associate director of Howard Hughes Medical Institute, so the Joslin was left with no apparent leader. It was a challenge I was happy to take on. When I got there, there were literally five people on the faculty in the research division and one of them left, so then there were four plus me. It was very small, but had the potential to grow and to become a really important part of diabetes research and a more important part of the Harvard medical environment.

JCI: It's always struck me that people who are truly hitting their academic stride are counterintuitively given more and more leadership, recruitment, and administrative burdens. How did you balance those tasks with what was an amazing research trajectory? It was at this time that you demonstrated that the insulin receptor is a tyrosine kinase receptor and then identified IRS1 \& -2 as the main paths for insulin receptor signaling.

Kahn: When I first got there, my major job was to recruit and build the Joslin up. But I had to wait until resources became available. This allowed me to focus significant time on my own research and allowed me to slowly and thoughtfully populate the Joslin with other investigators who would become leaders in the field. George King had come with me from NIH to become an independent investigator at the Joslin, and I recruited George Eisenbarth, who ultimately became the leader in type 1 diabetes of that era. I also recruited Bill Chin in molecular biology, Diane Mathis and Christophe Benoist in immunology, and also people doing clinical/epidemiological research, like Andrzej Krolewski. So this was a way I was able to grow research and able to keep my own research very focused. The hard part came when I became president and CEO of the Joslin. Then I had to be more disciplined about how to spend my time.
JCI: Where do you see the metabolism field going over the next 15 years?

Kahn: The interesting thing about science is the way every field has its ups and downs. Seems like everybody is into neuroscience now, while a few years ago, everyone was focused on immunology. Sometimes, people think metabolism is old science. In fact, Ben Lewin, the first editor of Cell, said to me when he rejected my manuscript without review, "Metabolism is old science, and we want to publish in this journal new science, like neuroscience and C.elegans."

But everything comes around, and metabolism is now at the heart of cancer biology and new therapies for cancer. It is also central to understanding the effects of the microbiome in gastroenterology, since microbes are emerging as "another organ" metabolizing our substrates and feeding us different kinds of nutrients that might positively or negatively affect us.

Thus, there's a surprising amount we still don't know about metabolism. In fact, even though we've learned a huge amount about insulin action and insulin resistance, if you ask me honestly, "Do we know the cause at a molecular or genetic level of the insulin resistance underlying type II diabetes, a disease that affects 30 plus million people in the US alone," I'd say the answer is no and that we have a lot to learn and that we need new ways of looking at these problems. I think there are going to be new hormones discovered and other new forms of communication between cells. For example, we're working on exosomal microRNAs being secreted by one cell and taken up by another cell as a new way of regulating gene expression.

JCI: What kind of an alternative career might you have sought other than being a clinician or a scientist?

Kahn: If I could steal somebody's talent and have another job, it would be to be a musician or a singer. I love music in all forms. I play three instruments - none very well - and I can't sing worth a darn. To be a Yo-Yo Ma or Itzhak Perlman or virtuoso singer who has a great voice, Pavarotti or someone like that, it would be so wonderful to be able to do something that not only gives you pleasure, but gives so many people pleasure when you do it.

Ushma S. Neill 